\title{
NADZAM DALAM I'JAZ AL QURAN MENURUT ABDUL QAHIR AL JURJANI
}

\author{
Ach. Thabrani* \\ STIBA Ar Raayah Sukabumi, Jawa Barat \\ Email: AhmadThabrani@gmail.com
}

\begin{abstract}
Abstrak
Mengkaji al Qur'an dari aspek sastra tidak dapat dilepaskan dari i'jaz al Qur'an itu sendiri. Diawali oleh Abu Ubaidah Mu'ammar ibn al Matsna (w.210 H) yang menulis buku judul Majaz al Qur'an kata majaz ini yang pertama kali digunakan dalam sejarah kajian balaghah. Kajian ini sangat berkaitan dengan dsiplin ilmu balaghah yang meliputi al Bayan, al Ma'ani dan Badi', bahkan ilmu sharaf dan ilmu nahwu. Tujuan dari penelitian ini adalah: (1) mengetahui biografi Abdul Qahir al Jurjani dan sejarah pemikirannya tentang i'jaz al Qur'an ditinjau dari teori struktur bahasa; (2) mengungkap teori Nadzam dalam i'jaz al Qur'an menurut Abdul Qahir al Jurjani beserta contohnya dalam al Qur'an. Penelitian ini menggunakan Kualitatif deskriptif analitis dengan literatur Kajian Pustaka. Hasil Penelitian adalah: (1) Abdul Qahir al Jurjani seorang pakar nahwu, ahli ilmu kalam dan bermadzhab asy'ary dengan pemikirannya melalui konsep an-nadzm. (2) Teori Nadzm menyatakan: (a) Al-Qur'an mengandung mukjizat dari aspek balaghah; (b) Kemukjizatan al-Qur'an terletak struktur atau susunan kebahasaan; (c) Karakteristik dan Essensi Nadzm dalam alQur'an tertuang pada hubungan antara lafazh dan makna yang tampak pada bait-bait syair yang mengikuti wazan dan kaidah arûdh.
\end{abstract}

Kata Kunci: Nadzam, i'jaz al Qur'an, Abdul Qahir al Jurjani

\section{PENDAHULUAN}

Dalam sejarah tercatat bahwa bangsa Arab Jahiliyah telah mencapai tingkatan yang tinggi dalam balaghah dan diksi. Mereka sangat bangga, lalu mengaplikasikannya ke dalam bentuk kalam seni prosa dan puisi. Sederet nama penyair terkenal semisal Zuhair Ibn Abi Salma, Amru Ibnu Kultsum, Tarfah, Al Khansa, Umru' al Qais, al Nabighah al Dubyani, Haris bin hillizah al 
Ach Thabrani: Nadzam Dalam I'jāz al Quran Menurut Abd al Qāhir al Jurjani

Yasykary, Lubaid bin Rabi'ah dan lainnya1, di mana mereka mengekspresikannya karya sastranya di pasar-pasar, seperti Ukaz(antara Mekah dan Thaif), Pasar Majnah (antara Mekah dan Zahran) dan pasar Dul Majaz (antara Mekah dan Mina) 2.Dan di antara karya-karya mereka yang berkualitas tinggi tersebut digantung di Ka'bah ${ }^{3}$, para linguis arab menamakan karya-karya mereka dengan "al Mua'alliqat" meskipun sebagian lain tidak sependapat karena Ka'bah mengalami banjir besar yang dapat menghancurkan karya-karya tersebut.

Dan dengan diturunkannya al Qur'an dan adanya hadits yang berbahasa Arab, hal ini semakin memperkaya dan memperkokoh eksitensi bahasa arab dalam bentuk kefashihan dan kebalaghahannya. Ayat-ayat al Qur'an selalu dibaca pada malam dan siang hari, ucapan Rasulullah Saw selalu ditiru oleh setiap lisan dan khutbah-khutbah beliau mendapatkan tempat di hati siapapun yang mendengarnya ${ }^{4}$.

Hal ini dapat dibuktikan dengan adanya riwayat bahwa al Walid al Mughirah salah satu orang kafir yang memusuhi Rasulullah Saw suatu hari mendengar beliau membaca al Qur'an, kemudian ia kembali kepada kaumnya Bani Makhtum sambil berkata :

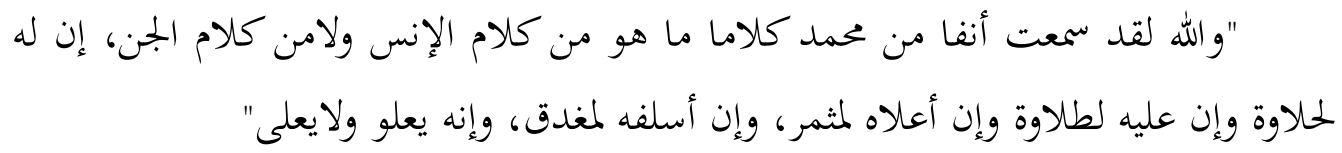

"sungguh aku tadi benar-benar telah mendengar dari Muhammad suatu ucapan yang bukan ucapan manusia yang bukan pula ucapan jin, alangkah manisnya ucapan itu, alangkah cantiknya ucapan itu, alangkah produktifnya

${ }^{1}$ Mayoritas linguis arab menggolongkan para penyair Arab menjadi empat golongan : al Jahiliyyun, al Mukhdaramun, al islamiyyun, al Muwallidun. Ramadan Abd Tawaab, Fushul Fi Fiqh al Lughah, Kairo : Maktabah al Khanjiy, tt, cet II, hal 101

${ }^{2}$ Abdullah Ali Muhammad Husain, al Bahts al Balaghi wal Marahil Tathawwurihi, Mesir: Mathba'ah al Amanah, 1992, hal $12-13$

${ }^{3}$ Abd al Aziz Ibnu Muhammad Faisal, al Adab al Arabiy wa Taarikhuhu, Riyadh: al Mamlakah al arabiyah as Su'udiyah, $1405 \mathrm{H}$, hal 75

${ }^{4}$ Syauqi Dhaif, al Balaghah Tathawwur wa Tarikh, Kairo : Dar al Ma'arif, tt, hal 13 
Ach Thabrani: Nadzam Dalam I'jāz al Quran Menurut Abd al Qāhir al Jurjani

ucapan itu dan sungguh ucapan itu amat tinggi ungkapannya dan tidak akan terkalahkan"

Abdul Qahir al Jurjani bertanya tanya : apakah i'jaz al Qur'an (kemukjizatan al Qur'an) itu lafadz atau maknanya? Berawal dari pertanyaan inilah Abdul Qahir al Jurjani tertarik untuk mengkajinya dari berbagai keunikan, keunggulan dan keistimewaan al Qur'an ini. Maka konsekwensi logisnya dari kajian ini menemukan berbagai macam disiplin ilmu seperti ilmu sharaf, nahwu dan ilmu balaghah yang meliputi al Bayan, al Ma'ani dan Badi'5.

Mengkaji al Qur'an dari aspek sastra tidak dapat dilepaskan dari i'jaz al Qur'an itu sendiri. Diawali oleh Abu Ubaidah Mu'ammar ibn al Matsna (w.210 H) yang menulis buku judul Majaz al Qur'an kata majaz ini yang pertama kali digunakan dalam sejarah kajian balaghah. Kemudian dilanjutkan oleh beberapa tokoh dari al Jahiz sampai Abdul Qahir Al Jurjani6.

Nadzm al Qur'an karya al Jahiz (w.255H), i'jaz al Qur'an karya muhammad Ibnu al Wasiti (w.306H), al Nukat fi i'jazil qur'an karya ali ibnu isa ar rumani (w.386H), bayan i'jaz al qur'an karya abu sulaiman al khattabi (w.388H), i'jaz al Qur'an karya Abu Bakar al Baqillani (w.403H) dan Dalailul I'jaz karya Abdul Qahir al Jurjani.

Dari penjelasan di atas, peneliti menyusun rumusan masalah yaitu: (1) Siapakah Abdul Qahir al Jurjani dan Bagaimana sejarah pemikirannya tentang i'jaz al Qur'an ditinjau dari teori struktur bahasa?; (2) Bagaimana teori Nadzam dalam i'jaz al Qur'an menurut Abdul Qahir al Jurjani beserta contohnya dalam Qur'an?

\footnotetext{
5.تسائل الجرجاني في معرض حديثه عن إعجاز القرأن، ماذا أعجز العرب، هل أعجزهم لفظ القرأن أم أعجزهم معناه، لا شك مل

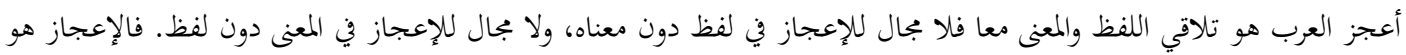

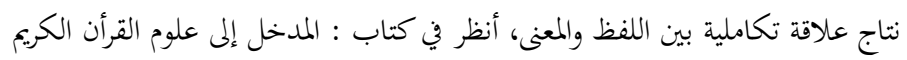

${ }^{6}$ Mahfudz Siddiq, Kajian Balaghah berbasis kearifan Lokal, Fakultas Tarbiya dan Keguruan UIN Walisongo Semarang, 2016, hal 41
} 


\section{METODE PENELITIAN}

Peneliti menggunakan pendekatan kualitatif deskriptif dengan triangulasi sumber data dari dokumen-dokumen dan literatur serta triangulasi teori dari teori struktur bahasa.

\section{PEMBAHASAN DAN HASIL}

\section{Biografi Abdul Qahir al Jurjani}

Abdul Qahir al Jurjani bernama Abu Bakar Abdul Qahir ibn Abdurrahman ibn Muhammad al Jurjani lahir pada abad 11 dan wafat pada tahun $471 \mathrm{H}$ di Gorgansalah satu kota terkenal yang terletak antara Tabaristan (Tibris) dan Khurasan7 Beliau dikenal di kalangan ahli balaghah sebagai Abdul Qahir al Jurjani seorang pakar nahwu, ahli ilmu kalam dan bermadzhab asy'ary ${ }^{8}$.

Dalam sejarah disebutkan bahwa Gorgan merupakan kota yang sangat indah sebagaimana diutarakan para sastrawan saat itu. Maka tidak mengherankan apabila kota tersebut menjadi perebutan penguasa saat itu hingga jatuhnya kekuasaan ke tangan penguasa Seljuk pada tahun $433 \mathrm{H}$ di mana mentrinya pada saat itu bernama Abi Ali Hasan bin Ali pendiri madrasah Nizamiyah yang merupakan institusi pendidikan pertama yang pernah ada di wilayah tersebut.

Melihat kondisi berbagai disiplin ilmu di kota tersebut membuat kesadaran Abdul Qahir Al Jurjani semakin kuat untuk mendalami ilmu-ilmu tersebut terutama ilmu ilmu bahasa arab. Dalam berbagai literatur memang tidak banyak diterangkan kepada siapa beliau belajar, namun bisa dipastikan ia lebih banyak belajar dari para ulama negeri kelahirannya. Di antara gurunya

${ }^{7}$ Syauqi Dhaif, al Balaghah Tathawwur wa Tarikh, hal 160

8 Abd al Aziz Atiq, Fi al Balaghah al Arabiyah 'ilm bayan, Beirut : Dar An Nahdah al Arabiyah, 1985, hal 22 
Ach Thabrani: Nadzam Dalam I'jāz al Quran Menurut Abd al Qāhir al Jurjani

yang paling terkenal adalah Abu Husain Muhammad An Nawawi yang mengajarkan kepadanya kitan al Idah.

Abdul qahir al Jurjani memiliki peran yang sangat besar dalam sejarah ilmu balaghah terutama kemampuannya dalam mengurai ilmu ma'ani dan ilmu bayan dengan uraian yang rinci sebagaimana beliau mengurai beberapa kesalahan dalam menganalisis gramatikal bahasa arab nahwu, teori pertama ilmu ma'ani ditulis secara rinci di dalam bukunya Dalailul i'jaz dan tentang ilmu bayan ditulis dalam bukunya Asrar al balaghah 9

Selain buku fenomenal tersebut, Abdul Qahir al Jurjani menulis beberapa karyanya : (1) al Madkhal fi dalail i'jaz (2) ara' al Jurjani (3) al Ijaz (4) al Maghna (5) al Muqtashad (6) al awamil al mi'ah (7) al Jumal (8) al talkhis (9) al Umdah fi al Tasrif (10) al Miftah(11) Al-Iqna' fi arudl wa takhrij qawafi(12)Mukhtar Ikhtiyar (13)Al-Tadzkarah.

\section{Dasar Pemikiran Abdul Qahir Al Jurjani}

Sejarah pemikiran Abdul Qahir al Jurjani bermula adanya Polemik yang paling keras dalam masalah yang terjadi di kalangan mutakallimin, terutama dengan kemunculan faham Mu'tazilah. Sebagai penganut aliran teologi Asy'ariyah, al-Jurjânî dalam bukunya dalailu i'jaz juga memberikan sanggahan terhadap pendapat al-Qâdhî 'Abd al-Jabbâr (w. 415 H), tokoh Mu'tazilah, mengenai i'jâz al-Qur'ân (inimitability of the Qur'ân) yang berpendapat bahwa kemukjizatan al-Qur'ân bukan terletak pada nazham. Jika ditelusuri akar historisnya, ilmu balâghah memang muncul dan berkembang karena terkait dengan wacana kemukjizatan al-Qur'ân, atau setidak-tidaknya digunakan untuk menjelaskan kemukjizatan al-Qur'an dari segi keindahan bahasa dan nilai sastranya. Al-Jâhizh (w. 255 H/868 M), misalnya, menganggap poros kemu'jizatan al-Qur'ân adalah nazham. Ar-Rummânî (w. 384 H) memandang

\footnotetext{
${ }^{9}$ Mahfudz Siddiq, Kajian Balaghah berbasis kearifan Lokal, hal 53
} 
Ach Thabrani: Nadzam Dalam I'jāz al Quran Menurut Abd al Qāhir al Jurjani

bahwa kemu'jizatan al-Qur'an terletak pada penentangan, tantangan, pemalingan atau pengalihan pandangan (shirfah), balâghah, berita yang terpercaya mengenai hal-hal yang akan terjadi di masa depan, dan berlawanan dengan kebiasaan. Sementara itu, Abû Hilâl al-'Askarî (w. 403 H) memahami letak kemu'jizatan al-Qur'ân pada alasan dan argumentasi memuaskan, dan hal ini diformulasikan oleh ilmu balâghah. Demikian pula, al-Bâqillânî (w. 403 H) berpendapat bahwa kemu'jizatan al-Qur'an itu disebabkan oleh adanya penginformasian hal-hal gaib, dan oleh keindahan nazham dan redaksinya yang tidak dapat dijangkau dan ditiru oleh manusia. Lebih lanjut, al-Qâdhî 'Abd al-Jabbâr berpendat bahwa kemu'jitan al-Qur'ân itu terletak pada posisi kalimat dan cara performansinya, bukan pada kata-kata tunggal, makna atau bentuknya ${ }^{10 .}$

Pendapat al-Qâdhî 'Abd al-Jabbâr itulah yang kemudian dibantah oleh alJurjâni, karena makna lafazh parsial itu tidak bertambah; yang bertambah adalah lafazh. Kelugasan dan kejelasan (fashâhah) itu tidaklah tampak pada parsialitas (ketunggalan) kosa kata, melainkan tampak pada struktur kata dalam kalimat. Karena itu, sumber keindahan sastra terletak pada dua hal, yaitu: keelokan dan kesempurnaan makna (husn al-dalâlah wa tamâmuhâ) dan keindahan bentuk lafazh ${ }^{11}$.

\section{Teori Nadzm dalam I'jaz al Qur'an}

Abdul Qahir al Jurjani memberikan pengertian Nadzm adalah sebagai berikut :

$$
\text { ويبنى بعضها على بعضم هو توخى معاني الإعراب، أن لا نظم في الكلام ولاترتيب حتى يعلق بعضها ببعض }
$$

10 Îd, Rajâ', Falsafah al-Balâghah: Baina al-Tiqniyyah wa al-Tathawwur, Alexandria: Munsya'at al-Ma'ârif, Cet. II, 1988, hlm 96

${ }^{11}$ Alwy Amru, Majaz: Telaah Pemikiran Abdul Qahir al-Jurjani, http://alwyamru. blogspot.com, diakses pada hari Rabu, 06 desember 2017 jam 12.43

12 Abu Bakr Abdul Qahir bin Abdur Rahman Al Jurjani, Dalailul i’jaz, Kairo : Maktabah al Khaniji, 2004, hal 55 
Nadzm adalah meredaksikan ungkapan dalam sebuah redaksi yang sesuai dengan aturan i'rob, tidak dikatakan Nadzm dalam sebuah ungkapan apabila tidak berkaitan dan tersusun dengan baik antara makna dan lafadznya.

Dalam Dalâil al-I'jâzz, dijelaskan bahwa "ruang lingkup bahasan nahwu harus lebih luas dari sekedar bahasan mengenai i'râb dan penentuan bunyi akhir kata. Nahwu harus mencakup bahasan mengenai nazham. Ketahuilah bahwa tidak disebut nazham (keteraturan struktur) kecuali jika engkau memosisikan pembicaraanmu pada posisi yang dikehendaki ilmu nahwu. Engkau mendasarkan pembacaraan itu pada kaidah-kaidah dan prinsipprinsipnya, dan engkau mengetahui metode yang mendasarinya, sehingga engkau tidak menyimpang darinya, dan engkau menjaga ancangan pembicaraan yang telah engkau tetapkan, sehingga tidak mengandung kecacatan sedikitpun." Unsur-unsur pembicaraan (dalam kalimat) harus memiliki relasi; yang satu menjadi penyebab yang lain, sehingga memberi makna. Nazham itu tidak mengacu pada lafazh semata, tetapi ketaraturan lafazh itu harus sesuai dengan makna, karena pembicaraan itu dapat tersusun secara baik karena keteraturan maknanya dalam diri pembicaranya.

Dalam keterangan yang lain juga diungkapkan bahwa Katanadzm berarti at-ta'lif (susunan, rangkaian, tatanan) ${ }^{13}$. Ini sebagaimana dikemukakan juga dalam al-Mu'jam al-Wasith, bahwa "nadzm al-Qur'an" :

$$
\text { عبارته التي تشتمل عليها المصاحف صيغة ولغة }
$$

"ungkapan-ungkapan al-Qur'an yang di dalamnya terkandung berbagai macam bentuk kata atau (unsur) bahasa"14

\footnotetext{
${ }^{13}$ Qamus al-Muhith, hlm. 1500, dan Lisan al-Arab, Juz 12, hlm. 578.

${ }^{14}$ Al-Mu'jam al-Wasith, Majma' al-Lughah al-Arabiyyah bi Mishr, Juz 2, hlm. 941.
} 


\section{I'jaz al Qur'an menurut Abdul Qahir al Jurjani}

I'jaz al Qur'an menurut Abdul Qahir al Jurjani terbagi menjadi tiga : 1). Mukjizat al Quran dari Balaghahnya 2). Mukjizat al Quran dalam Nadzmnya 3). Penjelasan esensi Nadzm

\section{Mukjizat al Qur'an dari Balaghahnya}

Menurut al Jurjani mukjizat al Qur'an adalah dari aspek balahahnya, oleh karenanya al Jurjani melakukan resistematisasi ilmu balâghah, khususnya 'ilm al-bayân dan 'ilm al-ma'ânî, al-Jurjânî dalam buku ini juga merumuskan teori kritik sastra dan teori nazham (structure,versification), sebuah teori mengenai keserasian struktur ungkapan (kalimat) dan baitbait syair sesuai dengan kaidah-kaidah nahwu. Karena itu, selain dikenal sebagai ahli balâghah, al-Jurjânî juga dianggap sebagai kritikus sastra dan peletak dasar teori nazham. Syauqi Dhaif, dalam al-Balâghah: Târîkh wa Tathawwur, bahkan menilai bahwa al-Jurjânî telah berhasil merumuskan teori 'Ilm al-Ma'ânî dan 'Ilm al-Bayân. Jika teori 'ilm al-ma'ânî dikodifikasikan dalam Dalâil al-I'jâz, maka teori 'ilm al-bayân dirumuskan dalam Asrâr al-Balâghah"15.

Keindahan lafazh, menurutnya, bukan terletak pada lafazh tunggal (yang berdiri sendiri), melainkan karena menjadi bagian dari struktur yang bermakna. Jadi, keindahan kata ditentukan oleh posisinya dalam struktur dan nazham, dan kontribusinya dalam makna keseluruhan dari struktur itu. Dalam hal ini, ia mencontohkan syair al-Buhturî sebagai berikut:

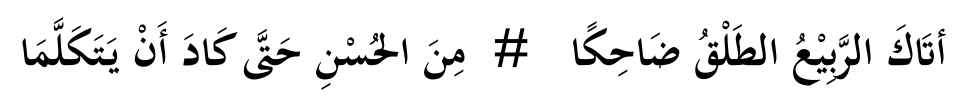

${ }^{15}$ Hasan, 'Abdullah 'Ali Muhammad, al-Bahts al-Balâghî wa Marâhil Tathawwurihi, Kairo: Mathba'ah al-Amânah, Cet. I, 1992, hlm 87 
Artinya: Musim semi yang indah berseri-seri menghampirimu dengan tawa,\#Lantaran kebaikannya, sehingga ia nyaris bertutur kata ${ }^{16}$.

Keindahan kata-kata dalam bait syair ini tidak terlihat pada kata per kata sebagai prosa, melainkan terletak pada keberkaitan (tarâbuth), hubungan atau relasi ('alâqah), dan keserasian (nasaq) semua kata dalam bait ini.

Mukjizat al Qur'an dari balaghahnya adalah ungkapan yang ada di dalam memiliki tingkat fashahah yang tinggi dan dari al Qur'an inilah melahirkan ilmu balaghah.

\section{Mukjizat al Quran dalam Nadzmnya}

Untuk mendukung konstruksi teori nazham-nya, al Jurjani juga mencontohkan ayat 2 surat al-Fâtihah:

$$
\text { الحمد الله رب العالمين }
$$

Kata-kata dalam redaksi ayat ini mengandung dua jenis makna, yaitu makna kata, seperti: al-hamd berarti pujian atau syukur yang paling tepat untuk hanya ditujukan kepada Allah Swt, dan makna nahwu, seperti: alibtidâ', al-ikhbâr, al-fi 'liyyah, al-maf'ûliyyah, al-zharfiyyah, dan sebagainya. Dari segi susunan redaksinya, ayat tersebut disusun sesuai dengan susunan nahwu: subyek (al-hamd)+prediket (li Allah). Ayat ini juga mengandung tiga jenis susunan, yaitu: susunan makna nahwu (tartîb ma'ânî al-nahwî), susunan makna kalimat atau ungkapan (tartîb ma'ânî alkalim) sesuai dengan susunan makna nahwu, dan susunan lafazh-lafazh 
sesuai dengan urutan maknanya ${ }^{17}$. Keindahan ketiga sususan tersebut, antara lain, dapat dijumpai dalam dua bait syair berikut:

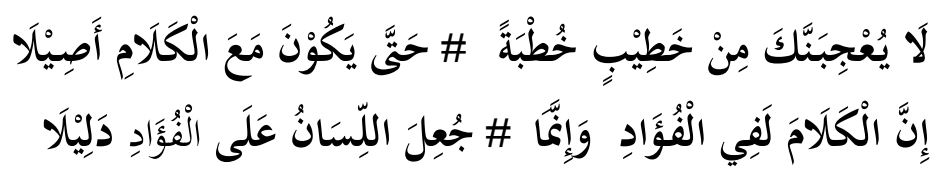

Artinya: Janganlah sekali-kali engkau terpesona oleh orasiseorangorator,\# hingga kalimat-kalimatnya itu disertai otentisitas (keaslian) ungkapan.

Kalimat-kalimat itu memang berada dalam hati nurani,\#sedangkan ekspresi bahasa itu dijadikan sebagai bukti (dalil) bagi hati nurani.

Di samping itu semua, teori kritik sastra yang dikembangkan alJurjânî juga berpangkal pada keindahan ekspresi. Keindahan ekspresi dimulai dari pemilihan kata yang tepat, akurat, padat dan bermakna. Kesesuaian struktur dengan gramatika, dan keserasian internal redaksi dengan makna yang dikehendaki juga menjadi kriteria dalam mengkritisi karya sastra Arab. Kritikus sastra juga disyaratkan mampu melihat relasi kontekstual (al-'alâqah al-siyâqiyyah) yang terjadi akibat adanya kesesuaian antara kaidah nahwu dan unsur-unsur kalimat dalam nilainilai ekspresi yang pada gilirannya mengekspresikan nilai-nilai emosional (perasaan).

\section{Esensi Nadzm}

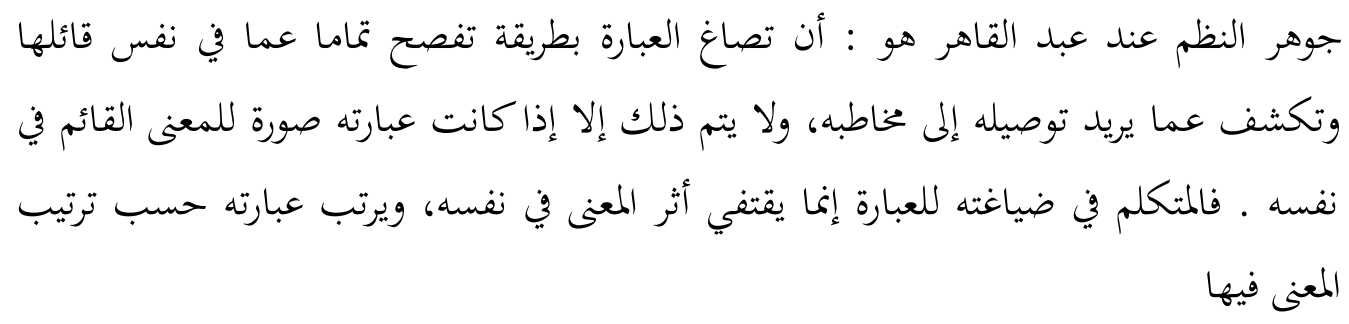

Esensi Nadzm menurut al Jurjani adalah membentuk ungkapan dengan cara mengungkapkan ungkapan tersebut dengan cara yang fashih

17 'Abbâs, Muhammad, al-'Ab'âd al-'Ibdâ'iyyah fi Manhaj 'Abd al-Qâhir al-Jurjânî, Damaskus: Dâr al-Fikr, 1999, hlm 174 
pada diri pembicaranya sehingga apa yang dikehendaki oleh pembicara tersebut sampai kepada orang yang diajak bicara, hal ini tidak akan bisa tercapai kecuali ada bentuk ungkapan yang maknanya tersampaikan kepada orang yang diajak berbicara. Maka pembicara dalam membuat ungkapan harus memperhatikan keteraturan maknanya.

Jadi, esensi teori nazham al-Jurjânî lebih menekankan pada hubungan antara lafazh dan makna dalam struktur kalimat yang serasi dan seimbang, seperti tampak pada bait-bait syair yang mengikuti wazan dan kaidah arûdh. Nazham merupakan aplikasi kaidah nahwu dalam redaksi suatu ungkapan. Dengan nazham kata-kata (lafazh) dapat distrukturkan menjadi redaksi yang indah, baik, bermakna dan komunikatif (memberikan pemahaman terhadap orang lain) ${ }^{18}$.

Tujuan akhir dari formulasi teori nazham adalah untuk: (1) mengetahui rahasia-rahasia keindahan dan kefasihan (balâghah) prosa maupun puisi, dan (2) mengetahui segi-segi kemukjizatan al-Qur'an, seperti: keelokan dan keserasian redaksi, keindahan struktur, kedalaman makna, dan kemudahan dan kealamian ekspresinya.

\section{Contoh Nadzam dalam al Quran dan Penejelasannya}

$$
\begin{aligned}
& \text { أ. (ولتجدفم أحرص الناس على حياة) البقرة } 96 \\
& \text { بيان سر التنكير وما جلبه من معان أضيفت إلى المعنى الأصلي ... كأنه قيل } \\
& \text { (ولتجدهم أحرص الناس - لو عاشوا ما عاشوا - على أن يزدادوا إلى حياتم في }
\end{aligned}
$$

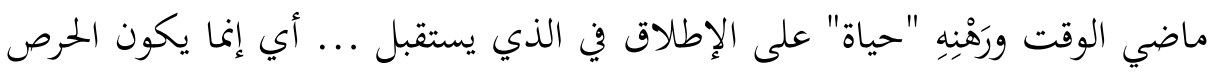

$$
\begin{aligned}
& \text { على ما لم يوجد بعد } 19 .
\end{aligned}
$$

${ }^{18}$ Al-'Azâwî, Ni'mah Rahîm, al-Naqd al-Lughawî 'Inda al-'Arab hatta Nihâyat al-Qarn alSâbi` al-Hijrî,Baghdâd: Dâr al-Hurriyah, 1978, hlm 153

${ }^{19}$ Abu Bakr Abdul Qahir bin Abdur Rahman Al Jurjani, Dalailul i’jaz, Kairo : Maktabah al Khaniji, 2004, hal 223 


$$
\begin{aligned}
& \text { ب. (وجعلوا لله شركاءَ الجحنَّ ... ) الأنعام } 100 \\
& \text {... إن لتقديم "شركاء" حسنا وروعة ومأخذا من القلوب، أنت لا تجد شيئا منه إذا }
\end{aligned}
$$

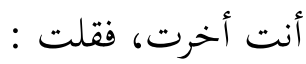

$$
\begin{aligned}
& \text { (وجعلوا الجن شركاء لله) فلم يكن في تأخير الشركاء أكثر من الإخبار عنهم بأفم } \\
& \text { عابدون الجن مع الله تعالى ... أما تقديم الشركاء يفيد هذا المعنى ويفيد معه شيء آخر } \\
& \text { وهو : ( أنه ما كان ينبغي أن يكون لله شريك من الجن ولا غير الجن). }
\end{aligned}
$$

\section{SIMPULAN}

Abdul Qahir al Jurjani bernama Abu Bakar Abdul Qahir ibn Abdurrahman ibn Muhammad al Jurjani lahir di Gorgan, salah satu kota terkenal yang terletak antara Tabaristan (Tibris) dan Khurasan Beliau dikenal di kalangan ahli balaghah sebagai Abdul Qahir al Jurjani seorang pakar nahwu, ahli ilmu kalam dan bermadzhab asy'ary. Dan sejarah pemikirannya adalah melalui konsep an-nadzm, kategori mukjizat al-Qur'an dalam pandangan al-Jurjani menjadi sangat jelas, bahwa aspek kemukjizatan bahasa al-Qur'an adalah nyata dan bukan karena faktor masyarakat Arab "dipalingkan" kemampuannya untuk membuat semisal al-Qur'an sebagaimana dikemukakan oleh penganut paham as-sharfah.

Teori Nadzm menurut Abdul Qahir Al Jurjani dalam i'jaz al Quran adalah : (1) Al-Qur'an mengandung mukjizat dari aspek balaghah; (2) Kemukjizatan al-Qur'an terletak pada nadzm (struktur atau susunan kebahasaan) yang digunakan; (3) Karakteristik dan Essensi Nadzm dalam alQur'an. Contoh nadzm dalam al Quran Kata حياة dalam ayat tersebut menggunakan isim nakiroh tidak menggunakan isim ma'rifat karena manusia rakus pada sesuatu tidak didapat setelahnya (QS. Al-Baqarah ayat 196) dan dalam Dalam ungkapan bahasa arab seharusnya mengedepankan kata jin tetapi dalam ayat tersebut mengedepankan kata شركلوا الجن شركاء agar 
memiliki makna yang tidak sempit, dan karena tidak ada sekutu bagi Allah baik jin, manusia dan makhluk lainnya (QS. Al-An'am ayat 100)

\section{DAFTAR PUSTAKA}

'Abbâs, Muhammad, al-'Ab'âd al-'Ibdâ'iyyah fi Manhaj 'Abd al-Qâhir alJurjânî, Damaskus: Dâr al-Fikr, 1999.

Abd al Aziz Ibnu Muhammad Faisal, al Adab al Arabiy wa Taarikhuhu, Riyadh : al Mamlakah al arabiyah as Su'udiyah, $1405 \mathrm{H}$

Abdul Ghani M Sa'd Barkah, al-I'jaz al-Qur'ani, Kairo: Maktabah Wahbah, 1989

Al Jurjani, Abu Bakr Abdul Qahir bin Abdur Rahman Dalailul i'jaz, Kairo : Maktabah al Khaniji, 2004

Al-'Azâwî, Ni'mah Rahîm, al-Naqd al-Lughawî 'Inda al-'Arab hatta Nihâyat al-Qarn al-Sâbi' al-Hijrî,Baghdâd: Dâr al-Hurriyah, 1978.

Al-Jurjani, Abdul Qahir bin Abdur Rahman Dalail al-I'jaz, Mathba'ah al-Manar, $1331 \mathrm{H}$

Al-Mu'jam al-Wasith, Majma' al-Lughah al-Arabiyyah bi Mishr, Juz 2

Amru, Alwy, Majaz: Telaah Pemikiran Abdul Qahir al-Jurjani, http://alwyamru. blogspot.com, diakses pada hari Rabu, 06 desember 2017 jam 12.43

Atiq, Abd al Aziz Fi al Balaghah al Arabiyah 'ilm bayan, Beirut : Dar An Nahdah al Arabiyah, 1985

Dhaif, Syauqi, al Balaghah Tathawwur wa Tarikh, Kairo : Dar al Ma'arif, tt Hasan, 'Abdullah 'Ali Muhammad, al-Bahts al-Balâghî wa Marâhil Tathawwurihi, Kairo: Mathba'ah al-Amânah, Cet. I, 1992. Hlm 87 Husain, Abdullah Ali Muhammad, al Bahts al Balaghi wal Marahil Tathawwurihi, Mesir : Mathba'ah al Amanah, 1992 
Ach Thabrani: Nadzam Dalam I'jāz al Quran Menurut Abd al Qāhir al Jurjani

Îd, Rajâ', Falsafah al-Balâghah: Baina al-Tiqniyyah wa al-Tathawwur, Alexandria: Munsya'at al-Ma'ârif, Cet. II, 1988.

Karîsyah, Abû Thâha Mushthafâ, Fî Mîzân al-Naqd al-Adabî, Kairo: tp., 1976.

Qamus al-Muhith, hlm. 1500, dan Lisan al-Arab, Juz 12

Siddiq, Mahfudz, Kajian Balaghah berbasis kearifan Lokal, Fakultas Tarbiya dan Keguruan UIN Walisongo Semarang, 2016

Tawaab, Ramadan Abd, Fushul Fi Fiqh al Lughah, Kairo : Maktabah al Khanjiy, tt, cet II 